\title{
The influence of size and shape of Nd:YAG capsulotomy on visual acuity and refraction
}

\author{
A influência do tamanho e forma da capsulotomia por laser de Nd:YAG sobre a acuidade visual e refração
}

Servet Cetinkaya ${ }^{1}$, Yasemin Fatma Cetinkaya ${ }^{2}$, Halil Ibrahim Yener ${ }^{3}$, Zeynep Dadaci ${ }^{4}$, Muammer Ozcimen ${ }^{5}$, Nursen Oncel Acir ${ }^{4}$

\begin{abstract}
Purpose: To evaluate the influence of size and shape of neodymium:yttrium aluminum-Garnet (Nd:YAG) laser capsulotomy on visual acuity and refraction.

Methods: We retrospectively evaluated 85 eyes of 67 patients treated with Nd:YAG laser posterior capsulotomy for posterior capsule opacification (PCO). The mean age of included patients was $57.57 \pm 9.26$ (mean \pm standard deviation, 38-75 years). The mean interval between surgery and Nd:YAG laser capsulotomy was $26.09 \pm$ 7.08 (10-38) months. Patients were divided into four groups according to the shape and size of capsulotomy. Groups comprised patients with cruciate shape capsulotomies with openings of less than or equal to $3.5 \mathrm{~mm}$ (Group 1) or greater (Group 2) and patients with circular shape capsulotomies with openings of less than or equal to $3.5 \mathrm{~mm}$ (Group 3) or greater (Group 4).

Results: The mean number and energy of laser firings were significantly higher in Group $4(p=0.00)$, and significantly lower in Group $1(p=0.00)$, compared with that in other groups. Pre-procedural and post-procedural mean spherical equivalent (SE) values were significantly higher in Group 1 ( $p=0.026$ and $p=0.011$, respectively). No statistical difference in best-corrected visual acuities (BCVA) or intraocular pressures (IOP) were observed between groups before $(p=0.44$ and $p=0.452$, respectively) or after capsulotomy ( $p=0.108$ and $p=0.125$, respectively). A significantly higher number of patients in Group $4(p=0.001)$, and a significantly lower number of patients in Group 1 ( $p=0.001$ ), reported floating bodies compared with that in other groups. No significant changes in SE or intraocular pressure were observed after capsulotomy in any group ( $p=0.074$ and $p=0.856$, respectively). Best-corrected visual acuity was significantly improved following capsulotomy in all groups $(p<0.01)$.

Conclusion: Cruciate shape capsulotomy with an opening of $3.5 \mathrm{~mm}$ or less pro-
\end{abstract} vides the greatest improvement in visual function with minimal complications.

Keywords: Cataract extraction; Phacoemulsification; Lens capsule, crystalline; Lens, intraocular; Laser therapy; Refraction, ocular; Visual acuity

\section{RESUMO}

Objetivo: Avaliar a influência do tamanho e forma da capsulotomia a laser de Neodímio:Itrio-Alumínio-Granada (Nd:YAG) na acuidade visual e refração.

Métodos: Oitentae cinco olhos de 67 pacientes, com opacificação de cápsula posterior (PCO), que tinham sido submetidos a capsulotomia porlaserde Nd:YAG, foram avaliadas retrospectivamente. A idade foi $57,57 \pm 9,26$ (média \pm desvio padrão), variação 38-75 anos. O intervalo médio entre a cirurgia e a capsulotomia a laser de Nd:YAG foi 26,09 \pm 7,08 (variação 10-38) meses. Os pacientes foram divididos em 4 grupos de acordo com a forma e o tamanho da capsulotomia. O grupo 1 incluiu pacientes com forma cruzada e tamanho igual ou menor do que 3,5 mm de abertura capsulotomia, Grupo 2, forma cruzada e tamanho maior do que 3,5 mm, Grupo 3, forma circular e tamanho igual ou menor do que 3,5 mm e Grupo 4, forma circular e tamanho superior a 3,5 $\mathrm{mm}$. Resultados: A quantidade média de energia utilizada e tiros aplicadas foram significativamente maiores no Grupo $4(p=0,00)$ e significativamente menores no grupo 1 $(p=0,00)$. Oequivalenteesférico (SE), antes eapós o procedimento, foi significativamente mais elevado no Grupo $1(p=0,026, p=0,011)$. Não houve diferença estatística entre os grupos em relação à acuidadevisual melhorcorrigida (BCVA) epressão intraocular (IOP) antes do procedimento $(p=0,44, p=0,452)$ e após o procedimento $(p=0,108, p=0,125)$. O número de pacientes com sintomas de moscas volantes foi significativamente maior no grupo $4(P=0,001)$ e significativamente inferior no grupo $1(p=0,001)$. SE e $I O P$ após o procedimento näo foram estatisticamente diferentes daqueles antes do procedimento ( $p=0,074, p=0,856$, respectivamente) em todos os grupos. BCVA após o procedimento foi significativamente melhor do que antes do procedimento $(p=0,00)$ em todos os grupos.

Conclusões: Em conclusão, para complicações mínimas e máximas funções visuais, o tamanho ótimo capsulotomia deve ser iqual a ou menor do que 3,5 $\mathrm{mm}$ e deve ser em forma cruzada.

Descritores: Extração de catarata; Facoemulsificação; Cápsula do cristalino; Lentes intraoculares; Terapia a laser; Refração ocular; Acuidade visual

\section{INTRODUCTION}

Posterior capsule opacification is the most common complication of cataract surgery and results from the proliferation and migration of residual lenticular epithelial cells ${ }^{(1-3)}$. Opacification may be diminished by atraumatic surgery, complete cleaning of cortex residues, polishing of both anterior and posterior capsules, or the use of specific intraocular lens (IOL) designs ${ }^{(1,4)}$. The overall incidence of posterior capsule opacification (PCO) approaches $50 \%$ at 5 years following cataract surgery ${ }^{(5-7)}$ and disproportionately affects younger patients due to higher cell proliferation rates ${ }^{(8)}$. PCO decreases visual acuity and contrast sensitivity leading to disability as a result of glare ${ }^{(9,10)}$. Nd:YAG laser capsulotomy has utility in the treatment of $\mathrm{PCO}$; however, a number of complications of this procedure have been reported including $I O L$ dislocation leading to hyperopia, IOL subluxation or luxation, IOP elevation, cystoid macular edema, and retinal detachment ${ }^{(11-13)}$.

A number of Nd:YAG laser capsulotomy shapes and sizes may be utilized. Cruciate and circular shapes are most commonly performed with a wide range of opening sizes (3-6 mm). Specific capsulotomy shapes and sizes confer particular advantages and disadvantages ${ }^{(14,15)}$. In this study, we evaluated the effect of $\mathrm{Nd}$ :YAG capsulotomy size and shape on visual outcomes.

\section{METHODS}

The study protocol was approved by the local ethics committee. Informed consent was obtained from patients prior to the procedure.
Submitted for publication: October 24, 2014

Accepted for publication: April 18, 2015

Ophthalmology Clinics, Turkish Red Crescent Hospital, Konya,Turkey.

Ophthalmology Clinics, Ataturk Training and Research Hospital, Ankara,Turkey.

${ }^{3}$ Konya Eye Centre Hospital, Konya,Turkey.

${ }^{4}$ Department of Ophthalmology, Faculty of Medicine, Mevlana University, Konya,Turkey.

${ }^{5}$ Department of Ophthalmology, Konya Training and Research Hospital, Konya,Turkey.
Funding: No specific financial support was available for this study.

Disclosure of potential conflicts of interest: None of the authors have any potential conflict of interest to disclose.

Correspondance author: Servet Cetinkaya. Turkish Red Crescent Hospital (Kizilay Hastanesi) - Ophthalmology Clinics, Sukran Mh. Taskapu Medrese Sok. №15 - Meram, Konya 42200 - Turkey E-mail: drservet42@gmail.com 
The study was carried out in accordance with the tenets of the Declaration of Helsinki.

We retrospectively evaluated 85 eyes of 67 patients treated with Nd:YAG laser posterior capsulotomy for PCO between November 2011 and July 2012. Phacoemulsification and IOL implantation surgery had previously been performed on all eyes, although at different times.

All patients reported blurred vision prior to surgical intervention. All Nd:YAG laser capsulotomy procedures were performed by a single surgeon (SC) under topical anesthesia using an ophthalmic Nd:YAG laser (Visulas YAG II, Zeiss, Germany) with capsulotomy contact lenses (Double aspheric capsulotomy lens, Volk, USA). One drop of a dorzolamid-timolol maleate combination was applied both before and after the procedure to prevent immediate increases in IOP following the procedure. A topical steroid (1\% dexamethasone sodium phosphate, Dexasine, Liba, USA) was prescribed for use 4 times a day for one week following the procedure.

Full ophthalmological examinations, including uncorrected visual acuity, best-corrected visual acuity (BCVA), refractive measurements, IOP measurements, biomicroscopic evaluation, and fundus examination, were performed both before and after the procedure. Patients with ocular or systemic diseases likely to affect vision were excluded from the study.

Patients were divided into 4 groups according to the shape and size of capsulotomy performed. Groups comprised patients with cruciate shape capsulotomies with openings of less than or equal to $3.5 \mathrm{~mm}$ (Group 1, 20 eyes) or greater (Group 2, 23 eyes) and patients with circular shape capsulotomies with openings of less than or equal to $3.5 \mathrm{~mm}$ (Group 3, 19 eyes) or greater (Group 4, 23 eyes).

$\mathrm{SE}, \mathrm{BCVA}$, and IOP were compared within groups and between groups prior to and at 1 month following capsulotomy. The number and energy of laser firings, and the number of patients reporting floating bodies, were also evaluated.

All statistical analyses were performed using commercially available statistical software (SPSS version 22, SPSS, Inc., Chicago, IL). Data were compared using the Chi-Square test, Wilcoxon Signed Ranks test, Mann-Whitney U test, or Kruger Wallis test as appropriate. P values of less than 0.05 were considered statistically significant.

\section{RESULTS}

Eighty-five eyes of 67 patients were included in this study. Thirty-two patients were male (47.7\%) and 35 were female (52.3\%). Forty-nine patients had unilateral PCO (73.1\%) and 18 patients had bilateral PCO (26.9\%). The mean age was $57.57 \pm 9.26$ years (38-75). The mean interval between surgery and Nd:YAG laser capsulotomy was $26.09 \pm 7.08$ months (10-38). No significant difference in the interval between surgery and Nd:YAG laser capsulotomy was observed between groups $(p=0.97)$. No statistically significant differences in age or gender were observed between groups ( $p=0.254$ and $p=0.49$, respectively).

The mean applied laser energy in Group 1 was $0.92 \pm 0.12$ milijoules (0.8-1.2), $1.26 \pm 0.15$ milijoules (0.9-1.5) in Group 2, $1.48 \pm 0.19$ milijoules (1.00-1.8) in Group 3, and $1.79 \pm 0.25$ milijoules (1.2-2.00) in Group 4. The mean applied laser energy was significantly greater in Group 4 compared with that in other groups ( $p=0.01$ ). The mean applied laser energy in Group 1 was significantly less compared with that in other groups ( $p=0.01$, Figure 1).

The mean number of laser firings was $42.65 \pm 11.62$ (32-72) in Group 1, $57.60 \pm 10.54$ (35-83) in Group 2, $77.15 \pm 13.17$ (50-99) in Group 3, and $84.69 \pm 13.44$ (65-110) in Group 4. The mean number of laser firings was significantly higher in Group 4 compared with that in other groups $(p=0.00)$. The mean number of laser firings was significantly lower in Group 1 compared other groups ( $p=0.00$, Figure 2).

The mean pre-procedural SE was $-0.92 \pm 0.67$ diopter (0.00-2.00) in Group 1, $-0.34 \pm 0.41$ diopter (0.00-1.00) in Group 2, $-0.50 \pm 0.52$ diopter (0.00-1.50) in Group 3, and $-0.50 \pm 0.67$ diopter (0.00-2.00) in Group 4. The mean pre-procedural SE was significantly higher (more myopic) in Group 1 ( $p=0.026$ ). The mean post-procedural SE was -0.92 \pm 0.74 diopter (0.00-2.00) in Group 1, $-0.26 \pm 0.42$ diopter (0.00-1.00) in Group 2, $-0.44 \pm 0.55$ diopter (0.00-1.50) in Group 3, and $-0.45 \pm$ 0.65 diopter (0.00-2.00) in Group 4. The mean post-procedural SE was significantly higher (more myopic) in Group 1 ( $p=0.011$, Figure 3). No significant change in SE following capsulotomy was observed in any group $(p=0.074)$.

The mean pre-procedural BCVA was $0.54 \pm 0.22$ logMAR units (0.20-0.90) in Group 1, $0.58 \pm 0.12$ logMAR units (0.20-0.80) in Group $2,0.54 \pm 0.23 \log M A R$ units (0.20-0.90) in Group 3, and $0.51 \pm 0.20$ logMAR units (0.20-0.90) in Group 4. There was no statistical difference between groups $(p=0.44)$. The mean post-procedural BCVA was 0.03 \pm 0.06 logMAR units (0.00-0.20) in Group 1, $0.008 \pm 0.02$ logMAR units (0.00-0.10) in Group 2, $0.05 \pm 0.07$ logMAR units (0.00-0.20) in Group 3, and $0.02 \pm 0.05 \log M A R$ units (0.00-0.20) in Group 4. There was no statistical differences between groups ( $p=0.108$, Figure 4 ). BCVA significantly improved in all groups following capsulotomy $(\mathrm{P}<0.01)$.

The mean pre-procedural IOP was $16.15 \pm 2.71 \mathrm{mmHg}(10-20)$ in Group 1, $14.86 \pm 2.63 \mathrm{mmHg}(11-19)$ in Group 2, $15.31 \pm 3.59 \mathrm{mmHg}$ (9-21) in Group 3, and $15.43 \pm 1.94 \mathrm{mmHg}(2-19)$ in Group 4. There was no statistical differences between groups $(p=0.452)$. The mean

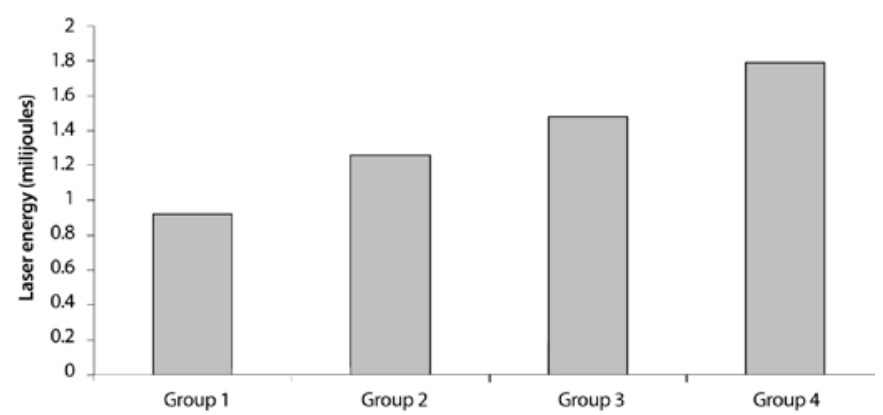

Figure 1. Mean laser energy used in each group.

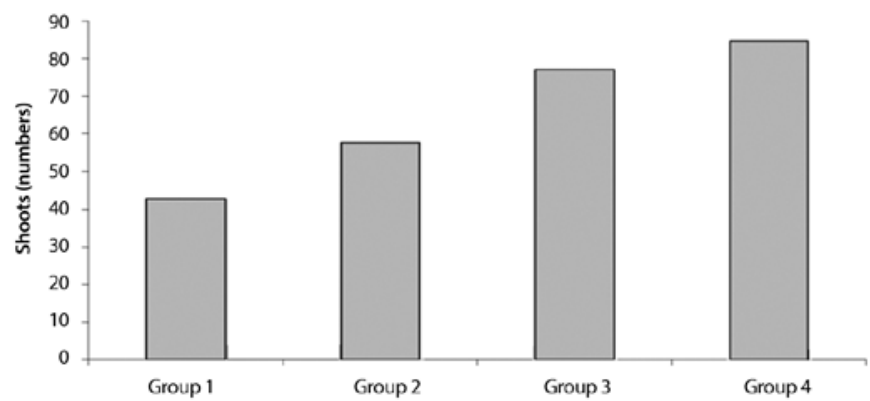

Figure 2. Mean laser firings in each group.

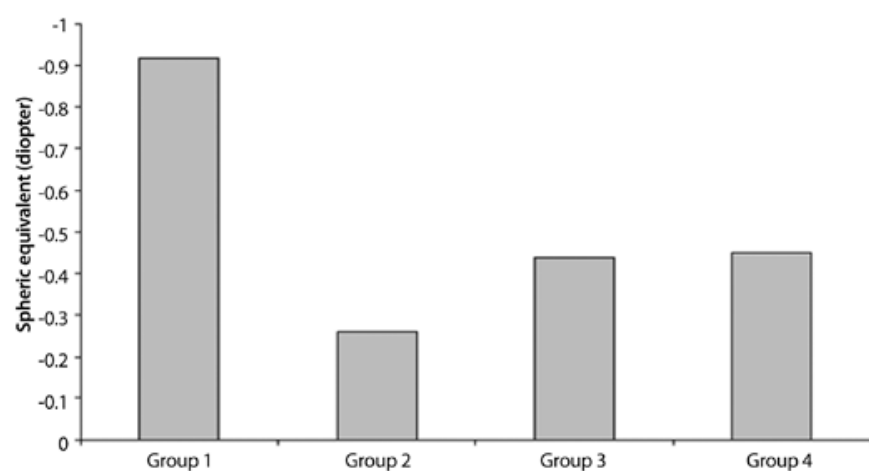

Figure 3. Mean post-procedural SE in each group. 
post-procedural IOP was $16.55 \pm 2.48 \mathrm{mmHg}(11-21)$ in Group 1,14.65 $\pm 2.56 \mathrm{mmHg}(10-18)$ in Group 2, $15.36 \pm 3.23 \mathrm{mmHg}(11-21)$ in Group 3 , and $15.34 \pm 1.96 \mathrm{mmHg}(12-19)$ in Group 4. There was no statistical differences between groups ( $p=0.125$, Figure 5). No significant change in IOP following capsulotomy was observed in any group $(p=0.856)$.

Floating bodies were reported in 2 eyes (10\%) in Group 1, 3 eyes (13\%) in Group 2, 7 eyes (36\%) in Group 3, and 14 eyes (60\%) in Group 4. Floaters were reported in a significantly higher proportion of eyes in Group 4 than in other groups $(p=0.001)$. Floaters were reported in a significantly lower proportion of eyes in Group 1 than in other groups ( $p=0.001$ ), however, no significant difference in the frequency of floating bodies was observed in Group $2(p=0.759)$ or Group 3 ( $p=0.05)$ compared with that in Group 1 (Figure 6).

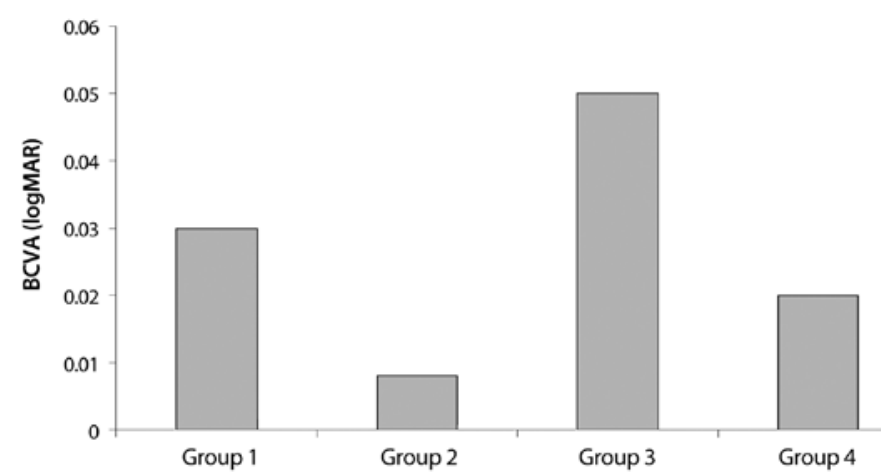

Figure 4. Mean post-procedural BCVA in each group.

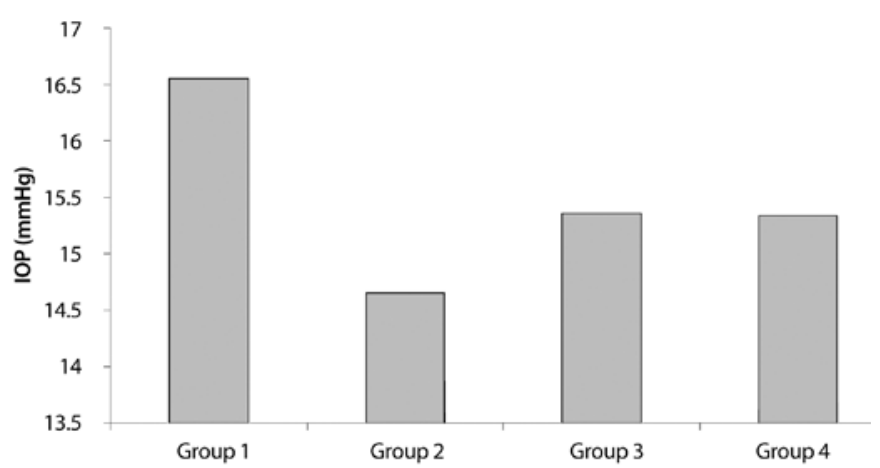

Figure 5. Mean post-procedural IOP in each group.

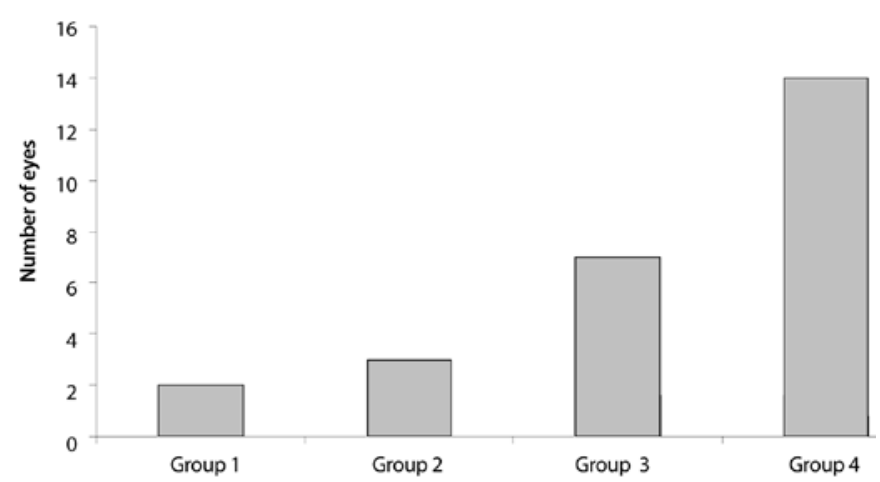

Figure 6. Number of patients reporting floaters in each group.

\section{DISCUSSION}

The main goal of Nd:YAG laser capsulotomy is to increase visual acuity, however improving contrast sensitivity and decreasing disability due to glare are also important ${ }^{(9,10,12)}$. Smaller capsulotomy openings limit visual acuity by diffraction and result in light passing through the unopened region of the capsule being scattered causing glare and decreasing contrast sensitivity. Capsulotomy opening should therefore be equal to, or larger than, the size of pupil in scotopic conditions ${ }^{(10,16)}$. However, capsulotomy openings should be large enough to ensure good visualisation of the peripheral fundus, particularly in patients with retinal disease.

On the other hand, larger capsulotomy openings may increase risk of cystoid macular edema, vitreous prolapse, and retinal detachment ${ }^{(11,17)}$ or cause posterior IOL dislocation leading to hyperopia ${ }^{(18)}$. In addition, a higher amount of energy is required that may increase the risk of retinal detachment ${ }^{(19)}$.

Refractive changes and visual acuity are usually not affected by the size and shape of capsulotomy ${ }^{(13-15)}$. However, floaters are more frequently reported, and the amount of energy used is higher, in circular shape capsulotomies ${ }^{(15)}$.

In our study we did not observe any complications related to Nd:YAG laser capsulotomy. Our study found no significant changes in refraction, visual acuity, or IOP in any groups following Nd:YAG capsulotomy. However, the amount of energy used, the number of laser firings, and the proportion of patients complaining of floaters were significantly higher in Group 4 (large, size circular shape capsulotomy). More energy and thus more laser firings are required to form larger circular shape capsulotomies resulting in more floating bodies in the anterior vitreous. Additionally, the amount of energy used, the number of laser firings, and floater complaints were significantly lower in Group 1 (small size, cruciate shape capsulotomy), however floater complaints in this group did not significantly less differ from Group 2 (big size, cruciate shape capsulotomy) or Group 3 (small size, circular shape capsulotomy).

In conclusion, cruciate shape capsulotomy with an opening of $3.5 \mathrm{~mm}$ or less provides the greatest improvement in visual function with minimal complications.

\section{REFERENCES}

1. Apple DJ, Solomon KD, Tetz MR, Assia El, Holland EY, Legler UF, et al. Posterior capsule opacification. Surv Ophthalmol. 1992;37(2):73-116.

2. Argento C, Zarate J. Study of the lens epithelial cell density in cataractous eye operated on with extracapsular and intracapsular techniques. J Cataract Refract Surg. 1990; 16(2):207-10.

3. Cobo LM, Ohsawa E, Chandler D, Arquello R, George G. Pathogenesis of capsular opacification after extracapsular cataract extraction. An animal model. Ophthalmology. 1984;91(7):857-63.

4. Baller R, Opacification of the posterior capsule-an alternative to discission. Ophthalmic Surg. 1997;8(6):48-50.

5. Apple D, Mamalis N, Loftfield K, Googe JM, Novak LJ, Kavka-Van Norman D, et al. Complications of intraocular lenses. A historical and histopathological review. Surv Ophthalmol. 1984;29(1):1-54.

6. Davis P, Hill P, Coffey A. Convex posterior PMMA implants: Do PMMA versus prolene haptics after capsular opacity? Eur J Implant Refract Surg. 1991;3(1):127-30.

7. Frezotti R, Caporossi A. Pathogenesis of posterior capsule opacification. Part I: Epidemiological and clinicostatistical data. J Cataract Refract Surg. 1990;16(3):347-52.

8. Mackool R, Chatiawala H. Pediatric cataract surgery and intraocular lens implantation: A new technique for preventing or excising postoperative secondary membranes. J Cataract Refract Surg. 1991;17(1):62-6.

9. Hayashi H, Nakao F, Hayashi H. Influence of size of Nd:YAG laser posterior capsulotomy on visual function. Eye (Lond). 2010;24(1):101-6.

10. Holladay JT, Bishop JE, Lewis JW. The optimal size of a posterior capsulotomy. J Am Intraocul Implant Soc J. 1985;11(1):18-20.

11. Patton N, Aslam TM, Bennett HG, Dhillon B. Does a small central Nd:YAG posterior capsulotomy improve peripheral fundal visualisation for the vitreoretinal surgeon? BMC Ophthalmol. 2004;4:8

12. Magno BV, Datiles MB, Lasa MS, Fajardo MR, Caruso RJ, Kaiser-Kupfer MI. Evaluation of visual function following Nd:YAG laser posterior capsulotomy. Ophthalmology. 1997; 104(8):1287-93. 
13. Chua CN, Gibson A, Kazakos DC. Refractive changes following Nd:YAG capsulotomy. Eye (Lon). 2001:15(Pt 3):304-5.

14. Yilmaz S, Ozdil MA, Bozkir N, Maden A. The effect of Nd:YAG laser capsulotomy size on refraction and visual acuity. J Refract Surg. 2006;22(7):719-21.

15. Kara N, Evcimen Y, Kirik F,Agachan A,Yigit FU. Comprasion of two laser capsulotomy techniques: cruciate versus circular. Sem Ophthalmol. 2014;29(3):151-5.

16. Nadler DJ, Jaffe NS, Clayman HM, Jaffe MS, Luscombe SM. Glare disability in eyes with intraocular lenses. Am J Ophthalmol. 1984;97(1):43-7.
17. Ranta P, Tommila P, Kivela T. Retinal breaks and detachment after neodymium: YAG laser posterior capsulotomy: five years incidence in a prospective cohort. J Cataract Refract Surg. 2004;30(1):65-73. Comment in: J Cataract Refract Surg. 2005;31(8):1480.

18. Findl O, Drexler W, Menapace R, Georgopoulos M, Rainer G, Hitzenberger CK, et al. Changes in intraocular lens position after neodymium:YAG capsulotomy. J Cataract Refract Surg. 1999;25(5):659-62. Comment in: J Cataract Refract Surg. 2000;26(1):5-6

19. Charles S. Vitreoretinal complications of YAG laser capsulotomy. Ophthalmol Clin North Am. 2001;14(4):705-10.

\section{Congresso Baiano de Oftalmologia VI Congresso da Sociedade Brasileira de Visão Subnormal}

Congresso Brasileiro de Trauma Ocular IX Congresso da Sociedade de Oftalmologia de Feira de Santana

VIII Simpósio LAOF

2 e 3 de outubro de 2015

Pestana Bahia Hotel

Salvador - BA

Informações:

Interlink Prime

Tel.: (71) 3011-9797

E-mail: indomar@interlinkeventos.com.br Site: www.interlinkeventos.com.br 